Tropical Journal of Pharmaceutical Research October 2021; 20 (10): 2109-2115

ISSN: $1596-5996$ (print); 1596-9827 (electronic) (C) Pharmacotherapy Group, Faculty of Pharmacy, University of Benin, Benin City, 300001 Nigeria.

\title{
Total phenolic and flavonoid contents, cytotoxic, immuno- modulatory and anti-inflammatory potential of whole plant of Astragalus creticus (Fabaceae)
}

\author{
Muhammad Abuzar Ghaffari ${ }^{1 *}$, Bashir Ahmad Chaudhry1, Muhammad Uzair ${ }^{1}$, \\ Muhammad Imran², Khuram Ashfaq ${ }^{3}$ \\ ${ }^{1}$ Department of Pharmaceutical Chemistry, Bahauddin Zakriya University, Multan 60800, Pakistan, ${ }^{2}$ Department of Chemistry, \\ King Khalid University, Abha 61413, Saudi Arabia, ${ }^{3}$ Lahore Pharmacy College, Lahore 53400, Pakistan \\ *For correspondence: Email: abuzarghaffarighaffari@yahoo.com; Tel: +92-333-6409496
}

Sent for review: 23 January 2021

Revised accepted: 18 September 2021

\begin{abstract}
Purpose: To determine total phenolic and flavonoid contents, as well as the cytotoxic, immunemodulatory and anti-inflammatory potentials of the whole plant of Astragalus creticus (Fabaceae).

Methods: Folin-Ciocalteu (FCR) method was used for determination of total phenolic and flavonoid contents of the methanol and dichloromethane extracts of Astragalus creticus. The cytotoxic potential of the extracts on $3 T 3$ and HeLa cell lines were evaluated using MTT assay. Brine shrimp larvae mortality was determined by lethality bioassay, while inhibitory effects were determined on mouse fibroblast (3T3) and cervical cancer (HeLa) cell lines. In vitro immunomodulatory and in vivo anti-inflammatory effects were assessed using reactive oxygen species (ROS) chemiluminescence and formalin-induced rat paw edema assays, respectively.

Results: Dichloromethane extract had higher contents of phenolics (TPC $=324.75 \pm 2.47 \mathrm{mg} \mathrm{GAE} / \mathrm{g}$ ) and flavonoids (TFC $=95.51 \pm 0.82 \mathrm{QE} / \mathrm{g}$ ) than the methanol extract (TPC $=79.82 \pm 1.53 \mathrm{mg} \mathrm{GAE} / \mathrm{g}$, $T F C=56.11 \pm 0.93 \mathrm{QE} / \mathrm{g})$. The dichloromethane extract exhibited high cytotoxic and immunomodulatory potentials, with $76.66 \%$ mortality in brine shrimp lethality bioassay and $83.9 \%$ inhibition $\left(I C_{50}=18.0 \pm 1.1 \mu \mathrm{g} / \mathrm{mL}\right)$ in chemiluminescence assay. The extract also resulted in 22 and 13 $\%$ inhibition of viability of HeLa and $3 T 3$ cells, respectively, while the methanol extract produced $13 \%$ inhibition of both cell lines. The methanol extract produced very significant anti-inflammatory activity, with a maximum of $49 \%$ inhibition of paw edema at a dose of $160 \mathrm{mg} / \mathrm{kg}(p<0.01)$.

Conclusion: These results suggest that the dichloromethane and methanol extracts of Astragalus creticus (Fabaceae) exert cytotoxic, immunomodulatory and anti-inflammatory effects. These findings provide scientific validation for the traditional medicinal use of the Astragalus genus.
\end{abstract}

Keywords: Astragalus creticus, Brine shrimp lethality, Flavonoid, Cytotoxic, Immunomodulatory activity

This is an Open Access article that uses a funding model which does not charge readers or their institutions for access and distributed under the terms of the Creative Commons Attribution License (http://creativecommons.org/licenses/by/4.0) and the Budapest Open Access Initiative (http://www.budapestopenaccessinitiative.org/read), which permit unrestricted use, distribution, and reproduction in any medium, provided the original work is properly credited.

Tropical Journal of Pharmaceutical Research is indexed by Science Citation Index (SciSearch), Scopus, International Pharmaceutical Abstract, Chemical Abstracts, Embase, Index Copernicus, EBSCO, African Index Medicus, JournalSeek, Journal Citation Reports/Science Edition, Directory of Open Access Journals (DOAJ), African Journal Online, Bioline International, Open-J-Gate and Pharmacy Abstracts

\section{INTRODUCTION}

Fabaceae is popularly known as the pea, legume or bean family which comprises 751 genera and 19000 species [1]. Astragalus creticus is an important plant of the Astragalus genus which is well known in the field of herbal medicine. Plants of Astragalus genus are 
traditionally used for treating various types of inflammation, healing of wounds, immunostimulation, and treatment of leukemia. Astragalus roots are used for preparation of popular herbal drugs in Traditional Chinese Medicine (TCM). These drugs exert hepatoprotective, immunostimulatory, antiinflammatory, anti-perspiration, antidiabetic, anticarcinogenic, and diuretic effects [2]. A list of traditionally-important Astragalus plants is presented in Table 1. Astragalus creticus is native to the mountainous areas of $\mathrm{S}$. Balkans, Candia, Greece and many parts of Asia. In Pakistan, this species is predominantly found in tribal areas of Southern Punjab and Baluchistan such as Sakhi Sarwar and Fort Manro. The plant, which has the common name of Cretan Milkvetch, is a rich source of high quality gum tragacanth [3].

The present study was designed as systematic and scientific investigations on the immunemodulatory, cytotoxic and anti-inflammatory potential of Astragalus criticus in order to validate its traditional and medicinal uses.

\section{EXPERIMENTAL} Plant collection, identification, and prepara-
tion of extracts

The plant was collected near Fort Manro (tribal area of southern Punjab) in March, 2014. It was identified as Astragalus creticus by a taxonomist at Institute of Pure and Applied Biology, Bahauddin Zakariya University, Multan, and voucher no. (www.the plantlist.org/tpl1.1/record/ ild.32000) was deposited at the herbarium of the institute. The whole plant of Astragalus creticus was shade-dried for 15 days, ground into coarse powder, and weighed. Then, $1000 \mathrm{~g}$ of the dried coarse powder was extracted using maceration in dichloromethane and methanol. The two extracts were concentrated using rotary evaporation under reduced pressure, and were labeled as ACWPD and ACWPM, for dichloromethane extract and methanol extract, respectively.

\section{Determination of total phenolic content (TPC)}

The test sample $(100 \mu \mathrm{L})$ was mixed with $10 \mu \mathrm{L}$ of $10 \%$ diluted FolinCiocalteu reagent (FCR), and incubated for $10 \mathrm{~min}$, followed by addition of $90 \mu \mathrm{L}$ of $15 \%(w / v)$ aqueous $\mathrm{Na}_{2} \mathrm{CO}_{3}$. The tube contents were pre-incubated at $37^{\circ} \mathrm{C}$ for $90 \mathrm{~min}$, prior to measurement of absorbance at $750 \mathrm{~nm}$. Gallic acid was used as positive control. Total phenolic contents (TPCs) were calculated from a gallic acid (GA) calibration curve, and expressed as mg of GA equivalents per gram of dry extract (mg GAE/g) [13]. Each assay was done in triplicate.

\section{Determination of total flavonoid content (TFC)}

A calibration curve was drawn using standard quercetin solution (1 $\mathrm{mg} / \mathrm{mL}$ in methanol). The test sample $(100 \mu \mathrm{L})$ was mixed with $25 \mu \mathrm{L}$ of 1 $\% \mathrm{NaNO}_{2}$ solution in a test tube, and allowed to stand for 5 min prior to addition of $10 \mu \mathrm{L}$ of $10 \%$ $\mathrm{AlCl}_{3}$ solution and $35 \mu \mathrm{L}$ of $4 \% \mathrm{NaOH}$.

Table 1: Traditional uses of various species of Astragalus genus

\begin{tabular}{|c|c|c|c|c|c|}
\hline Plant name & $\begin{array}{l}\text { Plant part } \\
\text { used }\end{array}$ & Traditional uses & Preparation & $\begin{array}{l}\text { Geographical } \\
\text { zone(s) }\end{array}$ & Reference \\
\hline A. membranaceus & Roots & $\begin{array}{l}\text { Anticancer and immunity } \\
\text { enhancement }\end{array}$ & $\begin{array}{l}\text { Decoction } \\
\text { and tincture }\end{array}$ & China & [4] \\
\hline A. pelecinus & Aerial parts & Healing of wounds & & Palestine & [5] \\
\hline A. chrysochlorus & Roots & $\begin{array}{l}\text { Healing of wounds and } \\
\text { treatment of leukemia. }\end{array}$ & $\begin{array}{l}\text { Aqueous } \\
\text { extract }\end{array}$ & Anatolia (Turkey) & [6] \\
\hline \multirow{3}{*}{ A. hamosus } & Pod & $\begin{array}{l}\text { Inflammation of liver, } \\
\text { ovaries, spleen and uterus }\end{array}$ & Decoction & $\begin{array}{l}\text { Afghanistan and } \\
\text { Pakistan }\end{array}$ & [7] \\
\hline & Fruits & Inflammation & Paste & $\begin{array}{l}\text { Afghanistan and } \\
\text { Pakistan }\end{array}$ & [8] \\
\hline & Aerial parts & Inflammation & Decoction & Iran & {$[\underline{9}]$} \\
\hline A. adsurgens & Roots & Healing of wounds & Decoction & Russia and Tibet & {$[10]$} \\
\hline A. alopecias & Whole plant & Healing of wounds & Powder & Russia and Tibet & [10] \\
\hline A. trojanus & Roots & Leukemia & $\begin{array}{l}\text { Aqueous } \\
\text { extract }\end{array}$ & Anatolia (Turkey) & [11] \\
\hline A. taipaishanensis & Roots & Enhancement of immunity & $\begin{array}{l}\text { Teas, } \\
\text { infusions and } \\
\text { decoction }\end{array}$ & $\begin{array}{l}\text { Taibai mountains } \\
\text { (China) }\end{array}$ & [12] \\
\hline A. creticus & & $\begin{array}{l}\text { High quality gum } \\
\text { tragacanth }\end{array}$ & & & [3] \\
\hline
\end{tabular}


Following dilution with $30 \mu \mathrm{L}$ of methanol, the absorbance of the solution was read at $510 \mathrm{~nm}$. The flavonoid contents were calculated and expressed as milligram of quercetin equivalents per gram of dry extract (mg QE/g DE) [13].

\section{Brine-shrimp lethality bioassay}

Artificial sea water was prepared by dissolving $3.8 \mathrm{~g}$ of sodium chloride (sea salt) in $1000 \mathrm{~mL}$ of $\mathrm{H}_{2} \mathrm{O}$, followed by filtration. Then, shrimp eggs were added to the water. When the eggs were hatched, the shrimp larvae were allowed to mature at $22-29{ }^{\circ} \mathrm{C}$ in 2 days. Then, graded concentrations of each extract $(10,100,1000$ $\mu \mathrm{g} / \mathrm{mL}$ was added in triplicate into different vials. Plant extract $(20 \mathrm{mg})$ was dissolved in $2 \mathrm{~mL}$ of solvent, and the sample was transferred at volumes of $5,50,500 \mu \mathrm{L}$ to vials to generate concentrations of $10,100,1000 \mu \mathrm{g} / \mathrm{mL}$, respectively. Etoposide was used as standard drug. To each vial, 10 shrimps and $5 \mathrm{~mL}$ sea water (30 shrimps/dilution) were added, followed by exposure to illuminating light for $24 \mathrm{~h}$. Shrimps that survived were counted and used for Probit analysis (Finney Computer program) [14].

\section{Cytotoxicity assay}

Cell viability was determined by checking the ability of the cells to oxidize 3-(4,5dimethylthiazol-2-yl)-2,5-diphenyl tetrazolium bromide (MTT reagent) and generate formazan crystals. The 3T3 and HeLa cells were cultured in Dulbecco's modified eagle medium (DMEM) and minimum essential medium eagle (MEME), respectively. The culture media were supplemented with penicillin (100 units $/ \mathrm{mL}$ ), $5 \%$ FBS, and streptomycin $(100 \mu \mathrm{g} / \mathrm{mL})$ in a $75-\mathrm{cm}^{2}$ culture flask, and placed in a $5 \%$ carbon dioxide incubator at $37^{\circ} \mathrm{C}$. The cells were counted with a hemocytometer, and diluted in appropriate specific medium. Each cell was cultured at a density of $5 \times 10^{4}$ cells $/ \mathrm{mL}$ in 96 -well plates at a volume of $100 \mu \mathrm{L}$ per well. After overnight incubation, the medium in each well was replaced with $200 \mu \mathrm{L}$ fresh medium containing a different concentration of sample extract, with extract concentrations ranging from 1 to $30 \mu \mathrm{M}$ ). Then, the wells were incubated for $48 \mathrm{~h}$, after which $200 \mu \mathrm{L}$ MTT $(0.5 \mathrm{mg} / \mathrm{mL})$ was added to each well, followed by further incubation for $4 \mathrm{~h}$. Thereafter, the medium in each well was discarded and replaced with $100 \mu \mathrm{L}$ of DMSO, in order to solubilize the resultant formazan crystals. The absorbance of the formazan solution in each well was measured at $540 \mathrm{~nm}$ in a Spectra Max plus microplate reader, and the inhibition of cell viability $(\mathrm{H})$ was calculated as shown in Eq 1.
$H(\%)=\{100-(A s-A n) /(A c-A n)\} \times 100$

where As, An and Ac are the absorbance of sample, negative and positive control samples, respectively.

Soft-Max Proof software (US) was used for calculation [15].

\section{Evaluation of immunomodulatory effect}

Diluted whole blood (1:5 in sterile PBS, $\mathrm{pH} 7.4$, $25 \mu \mathrm{L})$ and PMNs $\left(1 \times 10^{6}\right)$ suspended in $\mathrm{HBSS}^{++}$ were incubated with $25 \mu \mathrm{L}$ of various concentrations of each extract (1, 10 and 100 $\mu \mathrm{g} / \mathrm{mL}$ ) in triplicate in 96-well plates. The control wells contained only cells and $\mathrm{HBSS}^{++}$. Then 96well plates were incubated at $37^{\circ} \mathrm{C}$ for $15 \mathrm{~min}$ in a luminometer thermostat chamber. Thereafter, $25 \mu \mathrm{L}$ of SOZ and $25 \mu \mathrm{L}$ of ROS probe were introduced to each well. The ROS levels were determined in the luminometer in terms of RLU [16].

\section{Determination of anti-inflammatory activity}

White albino mice weighing 25-30 g were kept safely in steel cages and provided free access to standard chow feed and water in a wellventilated room at $25 \pm 2{ }^{\circ} \mathrm{C}$ at $12-\mathrm{h}$ light/12-h dark cycle. The animal experiments were carried out in strict compliance with the policies and protocols recommended by Institutional Animal Ethical Committee of Faculty of Pharmacy, Bahauddin Zakriya University, Multan. The committee also granted approval for the various experiments (approval ref no. 13/PEC/2019). International guidelines for animal studies were followed.

\section{Establishment of formalin-induced rat paw edema}

Albino mice were randomly assigned to 4 groups $(n=5)$. Group 1 mice received normal saline only, at a dose of $0.1 \mathrm{~mL} / \mathrm{kg}$. Group 2 was treated intraperitoneally with indomethacin at a dose of $10 \mathrm{mg} / \mathrm{kg}$, while ACWPM was administered to the $3^{\text {rd }}$ and $4^{\text {th }}$ experimental groups at doses 80 and $160 \mathrm{mg} / \mathrm{kg}$, respectively. Subcutaneous formalin injection $(10 \% \mathrm{w} / \mathrm{v} ; 0.5 \mathrm{~mL})$ was administered to groups 2, 3 and 4 after $30 \mathrm{~min}$ of their respective treatments as indicated above. Then, at $0,1,2$ and $3 \mathrm{~h}$ after the administration of formalin, paw size was measured by wrapping a cotton thread around each rat paw and measuring the length of the thread using a metric ruler [17]. 


\section{Statistical analysis}

All results are expressed as mean $\pm \operatorname{SEM}(n=5)$. Student's $t$-test was used for statistical analysis of differences between two groups, while oneway analysis of variance (ANOVA) and Dunnet's test for multiple comparisons were used to analyze differences in anti-inflammatory data among groups. All statistical analyses were done with SPSS version 24 software. Statistical significance of difference was assumed at $p<$ 0.05 .

\section{RESULTS}

Total phenolic (TPC) and total flavonoid contents (TFC)

Total phenolic and flavonoid contents were calculated in dichloromethane and methanol extracts of whole plant of Astragalus creticus. The results illustrate that dichloromethane extract (ACWPD) contained higher phenolic; $324.75 \pm$ 2.47 and flavonoid; $95.51 \pm 0.82$ contents as compared to methanol extract (ACWPM) of Astragalus creticus. The flavonoid/phenolic ratio (F/P) of ACWPD and ACWPM extracts was indicated at 0.29 and 0.70 , respectively (Table 2).

Table 2: TPC and TFC of the two Astragalus creticus extracts

\begin{tabular}{cccc}
\hline Extract & $\begin{array}{c}\text { TPC }(\mathbf{m g} \\
\text { GAE/g of } \\
\text { DE) }\end{array}$ & $\begin{array}{c}\text { TFC }(\mathbf{m g} \\
\mathbf{Q E} / \mathbf{g} \text { of } \\
\text { DE) }\end{array}$ & $\begin{array}{c}\text { Flavonoid: } \\
\text { phenolic } \\
(\mathbf{F}: \mathbf{P}) \text { ratio }\end{array}$ \\
\hline ACWPD & $324.75 \pm 2.47$ & $95.51 \pm 0.82$ & 0.29 \\
ACWPM & $79.82 \pm 1.53$ & $56.11 \pm 0.93$ & 0.70 \\
\hline
\end{tabular}

Values are expressed as mean \pm SEM

Table 3: Cytotoxic effect of Astragalus criticus extracts in brine shrimp lethality assay

\begin{tabular}{lcccc}
\hline Extract & $\begin{array}{c}\text { Concentration } \\
(\boldsymbol{\mu g} / \mathbf{m l})\end{array}$ & $\begin{array}{c}\text { No. of shrimps } \\
\text { taken }\end{array}$ & $\begin{array}{c}\text { No. of shrimps } \\
\text { that survived }\end{array}$ & Mortality (\%) \\
\hline ACWPD & 10 & 30 & 28 & 06.7 \\
& 100 & 30 & 27 & 10.0 \\
ACWPM & 1000 & 30 & 07 & 76.7 \\
& 10 & 30 & 27 & 10.0 \\
Etoposide (standard drug) & 100 & 30 & 25 & 16.7 \\
\hline
\end{tabular}

Table 4: Cytotoxic effect of Astragalus criticus extracts against $H e L a$ and $3 T 3$ cell lines assay

\begin{tabular}{lccc}
\hline \multirow{2}{*}{ Extract } & $\begin{array}{c}\text { Concentration } \\
(\boldsymbol{\mu g} / \mathbf{m L})\end{array}$ & \multicolumn{2}{c}{ Inhibition (\%) } \\
& 30 & 22 & 13 \\
\hline ACWPD & 30 & 13 & 13 \\
ACWPM & 30 & 70 & 70 \\
Cycloheximide (standard drug) & & 3T3 cell line (\%) \\
\hline
\end{tabular}

Trop J Pharm Res, October 2021; 20(10): 2112

\section{Brine-shrimp lethality bioassay}

The results showed that ACWPD produced better cytotoxic effect, with $6.66,10$ and $76.66 \%$ mortality values, than ACWPM which produced mortality values of $10,16.66$ and $20.00 \%$ 100 and $1000 \mu \mathrm{g} / \mathrm{mL}$, respectively. The drug (etoposide) resulted in $46.66 \%$ 3).

\section{Cytotoxicity against $3 T 3$ cell line}

Results from MTT assay on 3T3 cells revealed that ACWPD and ACWPM produced $13 \%$ inhibition, relative to the standard drug (cycloheximide) which produced $70 \%$ inhibition at $\mathrm{IC}_{50}$ of $0.8 \pm 0.2 \mu \mathrm{g} / \mathrm{mL}$ (Table 4 ).

\section{Cytotoxicity against HeLa cell line}

The anticancer effects of the extracts were further tested against HeLa cell lines using MTT assay. Both samples (ACWPD and ACWPM) produced moderate inhibitory effects: 22 and 13 $\%$ respectively, relative to the standard drug cycloheximide which produced $70 \%$ Inhibition at $\mathrm{IC}_{50}$ value of $1.2 \pm 0.2 \mu \mathrm{g} / \mathrm{mL}$ (Table 4 ).

\section{Immunomodulatory effect}

The immunomodulatory effects of ACWPD and ACWPM were determined using oxidative burst assay. The results showed that ACWPD exhibited high level of immunomodulatory effect, with $83.9 \%$ inhibition, and $\mathrm{IC}_{50}$ value of $18.0 \pm 1.1 \mu \mathrm{g} / \mathrm{mL}$. In contrast, ACWPM exerted against brine shrimp larvae at concentrations of mortality at a concentration of $7.46 \mu \mathrm{g} / \mathrm{mL}$ Table 
Table 5: Immunomodulatory effect of Astragalus creticus extracts

\begin{tabular}{lccc}
\hline Extract & $\begin{array}{c}\text { Concentration } \\
(\boldsymbol{\mu g} / \mathbf{m L})\end{array}$ & Inhibition $(\%)$ & IC $_{50}(\boldsymbol{\mu g} / \mathbf{m L})$ \\
\hline ACWPD & 25 & 83.9 & $18.0 \pm 1.1$ \\
ACWPM & 25 & 38.6 & $11.2 \pm 1.9$ \\
lbuprofen (standard & 25 & 73.2 & \\
drug) & & & \\
\hline
\end{tabular}

Table 6: Anti-inflammatory effects of Astragalus creticus extracts

\begin{tabular}{|c|c|c|c|c|c|c|c|c|}
\hline \multirow{2}{*}{ Group } & \multirow{2}{*}{$\begin{array}{l}\text { Dose } \\
(\mathrm{mg} / \mathrm{kg})\end{array}$} & \multicolumn{4}{|c|}{ Change in mean paw edema (cm) } & \multicolumn{3}{|c|}{ Inhibition (\%) } \\
\hline & & Normal & $1 \mathrm{~h}$ & $2 \mathrm{~h}$ & $3 \mathrm{~h}$ & $1 \mathrm{~h}$ & $2 \mathrm{~h}$ & $3 \mathrm{~h}$ \\
\hline Control & - & $1.04 \pm 0.17$ & $3.33 \pm 0.75$ & $4.45 \pm 0.31$ & $5.07 \pm 0.28$ & - & - & - \\
\hline Indomethacin & 10 & $0.99 \pm 0.08$ & $1.63 \pm 0.42^{* *}$ & $1.83 \pm 0.14^{\star *}$ & $1.97 \pm 0.12^{* *}$ & $51 \%$ & $59 \%$ & $61 \%$ \\
\hline ACWPM & 80 & $0.96 \pm 0.13$ & $2.43 \pm 0.46^{*}$ & $2.45 \pm 0.13^{* *}$ & $2.74 \pm 0.13^{\star *}$ & $26 \%$ & $46 \%$ & $45 \%$ \\
\hline ACWPM & 160 & $1.01 \pm 0.05$ & $2.43 \pm 0.52$ & $2.43 \pm 0.21^{*}$ & $2.56 \pm 0.17^{\star *}$ & $27 \%$ & $46 \%$ & $49 \%$ \\
\hline
\end{tabular}

moderate activity, with $38.6 \%$ inhibition, when compared with Ibuprofen (73.2 \% inhibition, with $\mathrm{IC}_{50}$ of $11.2 \pm 1.9 \mu \mathrm{g} / \mathrm{mL}$, Table 5$)$.

\section{Anti-inflammatory activity}

The values of $\%$ inhibition of inflammation for ACWPM and indomethacin (standard drug) were determined at various time intervals i.e., 1, 2 and $3 \mathrm{~h}$. The results showed that ACWPM exerted significant anti-inflammatory potential when tested at concentrations of 80 and $160 \mathrm{mg} / \mathrm{kg}$. The extract ACWPM produced a maximum of 46 $\%$ inhibition at a dose of $80 \mathrm{mg} / \mathrm{kg}$ after $2 \mathrm{~h}$. At a dose of $160 \mathrm{mg} / \mathrm{kg}$, ACWPM administration resulted in $49 \%$ inhibition of paw edema after 3 $\mathrm{h}$. The changes in mean paw edema and the corresponding \% inhibitions are presented in Table 6.

\section{DISCUSSION}

Phenolics are widely distributed in the plant kingdom. Studies have shown that phenolic compounds are beneficial for the prevention and treatment of bacterial and viral infections, as well as cancer and inflammatory diseases [18]. Thus, the quantification of phenolic compounds in plants is of paramount medicinal importance. Cancer is a malignant disease associated with millions of deaths worldwide. In 2015 alone, there were at least 17.5 million new cancer cases, and 8.7 million deaths worldwide [19]. In spite of all improvements in cancer therapy, survival from cancer is still low, and many cancer patients suffer from relapse as well as adverse effects of anti-cancer drugs. Moreover, the development of resistance to existing chemotherapeutic agents is a vital problem in cancer treatment. Therefore, there is need to evolve novel chemotherapeutic strategies for cancer [20].
The brine-shrimp lethality bioassay gives frontline cytotoxicity information which can be backed up with more sophisticated and specific bioassays. It has been reported that the brine shrimp lethality bioassay has a good correlation with the cytotoxicity of plant bioactive substances against some human solid tumors [14]. Indeed, several natural pesticidal and antitumor agents have been identified through screening using this assay. The 3T3 cells are mouse embryo fibroblasts colonial cells which are responsible for oncogenic activity of spontaneous human tumor-transfected DNA. Despite their limited susceptibility to transformation after transfection with DNA from neoplastic tissue, 3T3 cells play a vital role in the development of the molecular genetics of cellular oncogenes [21].

It has been revealed that the anticancer activities of plant extracts on HeLa cells are due to induction of apoptosis via the intrinsic and extrinsic pathways. This hypothesis is supported by previous studies which demonstrated the antiproliferative effects of extracts of Emilia sonchifolia, Solanum lyratum, Vatica diospyroides, Cotinus coggygri, Rosa damascene, Colchicum sanguicolle and Centaurea antiochia [22].The choice of HeLa cells is based on the fact that cervical cancer is the fourth most widely diagnosed cancer in women worldwide. Thus, new therapies are required for cervical cancer.

Reactive oxygen species (ROS) are generated via oxidative burst which has been implicated as the key underlying mechanism of tumoricidal and antimicrobial effects. Oxidative stress is closely linked to carcinogenesis because ROS function in various epigenetic factors involved in the induction, promotion, and modulation of cervical and breast cancers [24]. Recent findings indicate 
improved outcomes in the use of immunemodulatory drugs for treatment of cancer patients. Thus, ongoing investigations on the use of various treatment combinations for enhancing immunity against cancer are of prime importance in combating this disease [25].

Formalin-induced paw edema is a widely used experimental model for studying acute inflammatory response. Plant extracts that show anti-inflammatory potential are likely to inhibit the release of inflammatory mediators, and suppress accumulation of macrophages and neutrophils within 1-5 $\mathrm{h}$ following both phases of edema [26]. In this study, the results obtained with Astragalus creticus are consistent with the folkloric uses and experimentally-tested anti-inflammatory potential of various Astragalus species such as $A$. fasciculifolius, $A$. membranaceus, $A$. sinicus, $A$. gummifer, and $A$. hamosus [27]. Phenolic compounds derived from ginger (gingerol and 6shogaol) exhibit significant anticancer potential against breast, brain and lung cancers. The present study showed that Astragalus creticus extracts were rich in phenolic and flavonoid contents which were responsible for the observed cytotoxic effects against against brine shrimp lethality bioassay, 3T3 and HeLa cell lines [28].

\section{CONCLUSION}

The results of the present study demonstrate the potential cytotoxic, immunomodulatory and antiinflammatory activities of Astragalus creticus. Phenolics and flavonoids, being the major phytoconstituents, may be responsible for these activities. Further research is required, using other models, to elucidate the possible mechanism of action and to identify bioactive components that are responsible for the observed activities.

\section{DECLARATIONS}

\section{Acknowledgement}

Muhammad Imran expresses his appreciation to the Deanship of Scientific Research at King Khalid University, Saudi Arabia for funding this work through Research Groups Program (grant no. GRP-1/318/42).

\section{Conflict of interest}

No conflict of interest is associated with this study.

\section{Contribution of authors}

We declare that this work was done by the authors named in this article, and all liabilities pertaining to claims relating to the content of this article will be borne by the authors.

\section{Open Access}

This is an Open Access article that uses a funding model which does not charge readers or their institutions for access and distributed under the terms of the Creative Commons Attribution License (http://creativecommons.org/licenses/by/ 4.0) and the Budapest Open Access Initiative (http://www.budapestopenaccessinitiative.org/rea d), which permit unrestricted use, distribution, and reproduction in any medium, provided the original work is properly credited.

\section{REFERENCES}

1. Duke, James A. Caesalpinia spinosa. Handbook of Legumes of World Economic Importance. New York:Plenum Press; 1981; p 346.

2. Bensky, Dan; Clavey, Steven; Stöger, Erich; Gamble, Andrew, editors. Chinese herbal medicine: Materia medica. 3rd ed. Seattle: Eastland Press; 2004; pp 437440.

3. Stephenson, John; Churchill, James M. Medical Botany; Or, Illustrations and Descriptions of the Medicinal Plants of the London, Edinburgh, and Dublin Pharmacopoeias: Comprising a Popular and Scientific Account of Poisonous Vegetables that are Indigenous to Great Britain. London: J. Churchill; 1834; $p 338$.

4. Wang YP, Li $X Y$, Song CQ, Hu ZB. Effect of astragaloside IV on $T, B$ lymphocyte proliferation and peritoneal macrophage function in mice. Acta Pharmacol Sin 2002; 23(3): 263-266.

5. Jaradat NA, Al-Masri M, Zaid AN, Eid AM, Saleh AM, Zer AFA, Romi IM, Hussien A. Preliminary phytochemical screening and in-vitro evaluation of antioxidant and antimicrobial activities for Astragalus pelecinus from palestine. J Mater Environ Sci 2017; 8(4):1492-1497.

6. Karagöz A, Turgut-Kara N, Çakır Ö, Demirgan R, Arı Ş. Cytotoxic activity of crude extracts from Astragalus chrysochlorus (Leguminosae). BiotechnolBiotechnol Equip 2007; 21(2):220-222.

7. Usmani, Muhammad I. Tanqihul mufradat. Delhi:Famous Offset Press; 2008. p. 275

8. Hakim A, Ghufran A, Nasreen J. Evaluation of antiinflammatory activity of the pods of Iklil-ul-Malik (Astragalus hamosus Linn.). IJNPR 2010; 1: 34-37.

9. Hamedi $A$, Zarshenas MM, Sohrabpour $M$. Phytochemical assessments of Astragalus hamosus pods (Iklil-ul-Malik). Trends Pharm Sci 2016; 2(1):77-81.

10. Stepashkina KI. Astragalus and their application in clinic practice. KievMed Uni 1959:5-104.

Trop J Pharm Res, October 2021; 20(10): 2114 
11. Bedir E, Tatli II, Calis I, Khan IA. Trojanosides I-K: New cycloartane-type glycosides from the aerial parts of Astragalus trojanus. Chem Pharm Bull 2001; 49(11):1482-1486.

12. Xu WY, Luo JN. Study of Astragalus taipaishanensis in pharmacognosy. J Xi'an Med Uni 1988; 9:24-28.

13. Wolfe $K$, Wu X, Liu RH. Antioxidant activity of apple peels. J Agri Food Chem 2003; 51(3):609-614.

14. Meyer B, Ferrigni N, Putnam J, Jacobsen L, Nichols DJ, McLaughlin JL. Brine shrimp: a convenient general bioassay for active plant constituents. Planta Medica 1982; 45(5):31-34.

15. Rahman A, Choudhary MI, Thomsen WJ. Bioassay techniques for drug development. Harwood academic publishers, Canada. 2001; 14: 65-67.

16. Helfand SL, Werkmeister J, Roder JC. Chemiluminescence response of human natural killer cells. I. The relationship between target cell binding, chemiluminescence, and cytolysis. J Exp Med 1982; 156(2):492-505.

17. Fereidoni M, Ahmadiani A, Semnanian S, Javan M. An accurate and simple method for measurement of paw edema. J Pharmacol Toxicol Methods 2000; 43(1):1114.

18. Pawar SS, Dasgupta D. Quantification of phenolic content from stem-bark and root of Hugonia mystax Linn. using RP-HPLC. J King Saud Uni Sci 2018; 30(3):293-300.

19. Fitzmaurice C, Allen C, Barber RM, Barregard L, Bhutta ZA, Brenner H, Dicker DJ, Chimed-Orchir O, Dandona $R$, Dandona L. Global, regional, and national cancer incidence, mortality, years of life lost, years lived with disability, and disability-adjusted life-years for 32 cancer groups, 1990 to 2015: a systematic analysis for the global burden of disease study. JAMA Oncol 2017; 3(4):524-548.

20. Senthilkumar R, Bao-An C, Xiao-Hui C, Rong F. Anticancer and multidrug-resistance reversing potential of traditional medicinal plants and their bioactive compounds in leukemia cell lines. Chin J Nat Med 2014; 12(12):881-894.

21. Rubin H. Dynamics of cell transformation in culture and its significance for tumor development in animals. Proc Natl Acad Sci 2017; 114(46):12237-12242.

22. Artun FT, Karagoz A, Ozcan G, Melikoglu G, Anil S, Kultur S, Sutlupinar N. In vitro anticancer and cytotoxic activities of some plant extracts on HeLa and Vero cell lines. J BUON 2016; 21(3):720-725.

23. Calaf GM, Urzua U, Termini L, Aguayo F. Oxidative stress in female cancers. Oncotarget 2018; 9(34):23824-23842.

24. Matsushita $M$, Kawaguchi M. Immunomodulatory effects of drugs for effective cancer immunotherapy. J Oncol 2018: 2018.

25. Ashfaq K, Choudhary BA, Uzair M, Hussain SN, Ghaffari MA, Sarwar W, Manzoor M. Antipyretic, analgesic and anti-inflammatory activities of methanol extract of root bark of Acacia jacquemontii Benth (Fabaceae) in experimental animals. Trop J Pharm Res 2016; 15(9): 1859-1863.

26. Shahrani M, Asgharzadeh N, Torki A, Asgharian S, Lorigooini Z. Astragalus fasciculifolius manna; antinociceptive, anti-inflammatory and antioxidant properties in mice. Immunopathol Persa 2020; 7(1):e02.

27. Yanez J, Vicente V, Alcaraz M, Castillo J, BenaventeGarcia O, Canteras M and Teruel JAL. Cytotoxicity and antiproliferative activities of several phenolic compounds against three melanocytes cell lines: Relationship between structure and activity. Nutr. Cancer 2004; 49: 191-199.

28. Yanez J, Vicente V, Alcaraz M, Castillo J, BenaventeGarcia O, Canteras M and Teruel JAL. Cytotoxicity and antiproliferative activities of several phenolic compounds against three melanocytes cell lines: Relationship between structure and activity. Nutr. Cancer 2004; 49: 191-199 